NOTE

\title{
Strong effects of herbivorous amphipods on epiphyte biomass in a temperate seagrass meadow
}

\author{
Kylie Cook $^{1, *}$, Mathew A. Vanderklift ${ }^{1}$, Alistair G. B. Poore ${ }^{2}$ \\ ${ }^{1}$ CSIRO Wealth from Oceans Flagship, Private Bag 5, Wembley, Western Australia 6913, Australia \\ ${ }^{2}$ Evolution and Ecology Research Centre \& School of Biological, Earth and Environmental Sciences, \\ University of New South Wales, Sydney, New South Wales 2052, Australia
}

\begin{abstract}
The experimental manipulation of large marine herbivores (urchins, gastropods and fish) has repeatedly demonstrated their strong influence on the abundance and composition of benthic primary producers. However, the effects of smaller herbivores (amphipods, isopods and small gastropods) on community structure are not as well understood. We used a cageless technique (a slow-release insecticide) to exclude amphipods from seagrass meadows to test for their effects on epiphyte and seagrass biomass. Lower amphipod densities in a Posidonia sinuosa meadow after 7 wk were associated with $25 \%$ higher epiphyte biomass - evidence of a strong influence by amphipods on seagrass epiphytes. In an Amphibolis spp. meadow, lower amphipod densities showed a non-significant trend to increase leaf epiphytes, but did not affect stem epiphyte biomass. Effects of amphipod exclusion on seagrass biomass were not detected in either meadow. Our results indicate that natural densities of amphipods can reduce epiphyte biomass on seagrasses, but that their impacts may vary across seagrass meadows. A challenge for future research is to identify the conditions under which small marine herbivores are likely to influence the biomass of primary producers.
\end{abstract}

KEY WORDS: Herbivory · Mesograzer $\cdot$ Amphipods $\cdot$ Seagrass $\cdot$ Epiphytes $\cdot$ Field exclusion

\section{INTRODUCTION}

Herbivores frequently control the abundance and composition of primary producers, but the strength of their impacts varies profoundly among habitats, and with the identity, size and abundance of herbivores and primary producers (Shurin et al. 2006). In marine ecosystems, the strong effects of large herbivores (fish, sea urchins and large gastropods) on benthic primary producers are well documented in field experiments (Lubchenco \& Gaines 1981, Heck \& Valentine 2006). Given the abundance and ubiquity of smaller grazers (amphipods, isopods and gastropods; collectively termed mesograzers) in macroalgal and seagrass beds worldwide, they might have similar ecological importance.

To date, the effects of mesograzers are mostly studied in a laboratory or mesocosm setting (Poore et al. 2009), largely because of logistical difficulties associated with manipulating their densities under field conditions. Exclusion cages for such small organisms require a small mesh size, resulting in increased shading, reductions in water flow and changes to rates of sedimentation, all of which may confound experimental results (e.g. Jernakoff \& Nielsen 1997). Experiments involving the enclosure of animals at a single density face the same possible caging artefacts and the problem that the densities of these highly mo- 
bile animals in the field are highly variable in space and time (Edgar 1992, Taylor 1998, Poore 2005).

Despite limitations in some previous studies, there is increasing evidence that mesograzers have the potential to alter the structure of macroalgae and seagrass communities. Observations of mesograzer damage in field populations of macroalgae (Graham 2002, Haggitt \& Babcock 2003), correlations between grazer and primary-producer densities (Aikins \& Kikuchi 2002), results of mesocosm studies (Duffy \& Hay 2000, Duffy et al. 2001, Jaschinski \& Sommer 2008) and manipulations of mesograzers via caging (e.g. Korpinen et al. 2007) or exclusion of predatory fish (Davenport \& Anderson 2007) have all indicated that mesograzers can reduce the biomass of primary producers.

In seagrass meadows, mesograzers are frequently diverse and abundant, and many taxa, including amphipods, feed primarily on epiphytic algae (Jernakoff et al. 1996, Valentine \& Duffy 2006). Epiphytes can comprise a high proportion of the primaryproducer biomass in a seagrass meadow, even equalling the biomass of the seagrass host in mixed Amphibolis (A. griffithii/A. antarctica) meadows of Western Australia (Edgar 1990). When abundant, epiphytes can compete with seagrass for light, thereby having a detrimental effect on their host (Silberstein et al. 1986, Jernakoff et al. 1996). By reducing epiphyte biomass, mesograzers are commonly assumed to benefit seagrasses (Hughes et al. 2004). Evidence for a strong influence by mesograzers on epiphytes, however, is primarily based on laboratory or mesocosm studies (reviewed in Valentine \& Duffy 2006), and evidence from field experiments is surprisingly rare and predominantly focused on the use of predators to reduce mesograzer densities (Heck et al. 2000, 2006, Douglass et al. 2007).

We used a new cageless technique to examine the effects of natural densities of grazing amphipods in seagrass beds. Poore et al. (2009) described a method of effectively excluding amphipods without cages using the insecticide carbaryl in a slow-release plaster matrix. Previously, insecticides have been used to remove amphipods from mesocosms and aquaculture facilities (Shacklock \& Croft 1981, Duffy \& Hay 2000, Douglass et al. 2008), but attempts to manipulate densities in field conditions (Carpenter 1986, Brawley \& Fei 1987, Bruno et al. 2005) were hampered by its rapid breakdown in seawater and light, combined with the rapid re-colonisation of amphipods. Incorporating the insecticide into a slow-release matrix overcomes the need for frequent reapplications, and allows for high levels of replication with interspersed treatments (Poore et al. 2009).
We used this method to test whether reducing natural abundances of herbivorous amphipods in field conditions would affect the biomass of epiphytic algae in seagrass meadows in Western Australia, and whether there would be subsequent changes in seagrass biomass.

\section{MATERIALS AND METHODS}

Field experiments were conducted in 2 seagrass meadows in Cockburn Sound, Western Australia $\left(32^{\circ} 9^{\prime} 32^{\prime \prime} \mathrm{S}, 115^{\circ} 40^{\prime} 10^{\prime \prime} \mathrm{E}\right)$ : one dominated by Posidonia sinuosa (hereinafter called 'Posidonia meadow') and one dominated by a mixture of Amphibolis griffithi and A. antarctica (hereinafter called 'Amphibolis meadow'). The meadows were located in a sheltered bay on the eastern side of Garden Island, in water depths of 0.5 to $2 \mathrm{~m}$. Herbivorous amphipods in the families Ampithoidae, Aoridae, Eusiridae and Hyalidae comprise $>94 \%$ of amphipod individuals inhabiting seagrasses at Garden Island (P. Vouriot, A. G. B. Poore \& M. A. Vanderklift unpubl. data).

The insecticide carbaryl (1-naphthyl- $N$-methylcarbamate) has been previously used to exclude amphipods in mesocosms and aquaculture facilities and field-based exclusion experiments (Carpenter 1986, Poore et al. 2009). Carbaryl is also used to control a variety of terrestrial arthropods by disrupting the nervous system (Tomlin 2000). Carbaryl has no known effect on epiphytic algae (Poore et al. 2009) and breaks down rapidly, with a half-life of $5 \mathrm{~h}$ in seawater and light (Armhurst \& Grosby 1991). Previous studies have also reported no effect on isopods, gastropods or fishes (Duffy \& Hay 2000, Poore et al. 2009). Mixing $80 \%$ carbaryl wettable powder into a plaster matrix allows the carbaryl to be released slowly over a period of several days. We made plaster blocks containing $7.6 \%$ carbaryl by weight (hereinafter called 'carbaryl'), and plaster blocks without carbaryl (to control for the potential effects of the plaster, hereinafter called 'plaster') following the methods established by Poore et al. (2009). The blocks were cast in $100 \mathrm{ml}$ moulds and a hole was pushed through the centre before blocks were completely set. The blocks were then placed on a metal tent peg, which could be pushed into the sediment in the field with minimal disturbance to the surrounding sediment and seagrass.

We conducted a pilot study (3 to 10 September 2009) to confirm that this method effectively reduced amphipod densities in our seagrass meadows. Amphipod densities were strongly reduced when 
sampled $10 \mathrm{~cm}$ away from the carbaryl blocks, but densities in plots $50 \mathrm{~cm}$ away did not differ from control plots (Tukey's post hoc analyses, $\mathrm{p}=0.211$ ).

We then conducted a $7 \mathrm{wk}$ field experiment between 16 October and 4 November 2009 to test whether reduced amphipod densities had an effect on epiphyte or seagrass biomass. Carbaryl, plaster and control (with plot marker only) treatments ( $\mathrm{n}=10$ per treatment) were randomly placed within a grid pattern with at least $2 \mathrm{~m}$ between plots. Each plot was considered to be a circular area around a central marker with a radius of $10 \mathrm{~cm}$ (the results of our pilot study found the treatment to be effective over this distance). The experiment was conducted in each of the 2 seagrass meadows, which were approximately $500 \mathrm{~m}$ apart. The plots were maintained by replacing the plaster blocks (carbaryl and plaster controls) every $7 \mathrm{~d}$ for the first $2 \mathrm{wk}$, then every $5 \mathrm{~d}$ due to increased dissolution rates (probably resulting from warmer water temperatures).

At the end of the experiment, seagrass in the plots was sampled using a $65 \mathrm{~mm}$ internal diameter PVC tube attached to a calico bag placed over the seagrass $10 \mathrm{~cm}$ away from the plaster block (or peg for control plots). The seagrass was then cut at the sediment level using gardening shears, and the calico bag tied closed. Seagrass was not sampled immediately adjacent to the peg to minimise any potential effects of disturbance from replacing the blocks. In the laboratory, epiphytes were removed from the seagrass by scraping with a razor blade. The epiphytes on Amphibolis spp. were separated into leaf and stem epiphytes, because the composition of epiphytes on stems and leaves is typically different (Lavery \& Vanderklift 2002). Stem epiphytes were predominantly macroalgae that were large enough to be sorted into calcareous and non-calcareous groups. Seagrass and epiphytes were then dried in an oven at $60^{\circ} \mathrm{C}$ for $48 \mathrm{~h}$.

Differences in mesograzer abundance (separated into 3 groups: amphipods, isopods and gastropods) and epiphyte biomass among treatments were tested by analysis of covariance (ANCOVA; with seagrass biomass as the covariate). Differences in seagrass biomass among treatments were tested by ANOVA. Data were first assessed for normality using the Shapiro-Wilk test and for equality of variances using Levene's test and all data were log transformed. When analyses revealed significant differences among treatments, Tukey's post hoc tests were used to resolve the nature of differences among treatment means. Analyses were conducted using SYSTAT version 12 .

\section{RESULTS}

Carbaryl was very effective in reducing amphipod abundance in both seagrass meadows (Fig. 1, Table 1). Mean amphipod densities were $90 \%$ lower in the carbaryl treatment in the Posidonia meadow $\left(19.62 \pm 3.05\right.$ ind. $\mathrm{g}^{-1}$ seagrass in control plots versus $1.94 \pm 0.42$ ind. $\mathrm{g}^{-1}$ seagrass in carbaryl plots; Fig. 1a) and $86 \%$ lower in the Amphibolis meadow (65.23 \pm 14.16 versus $8.95 \pm 1.21$ ind. $\mathrm{g}^{-1}$ seagrass, respec-

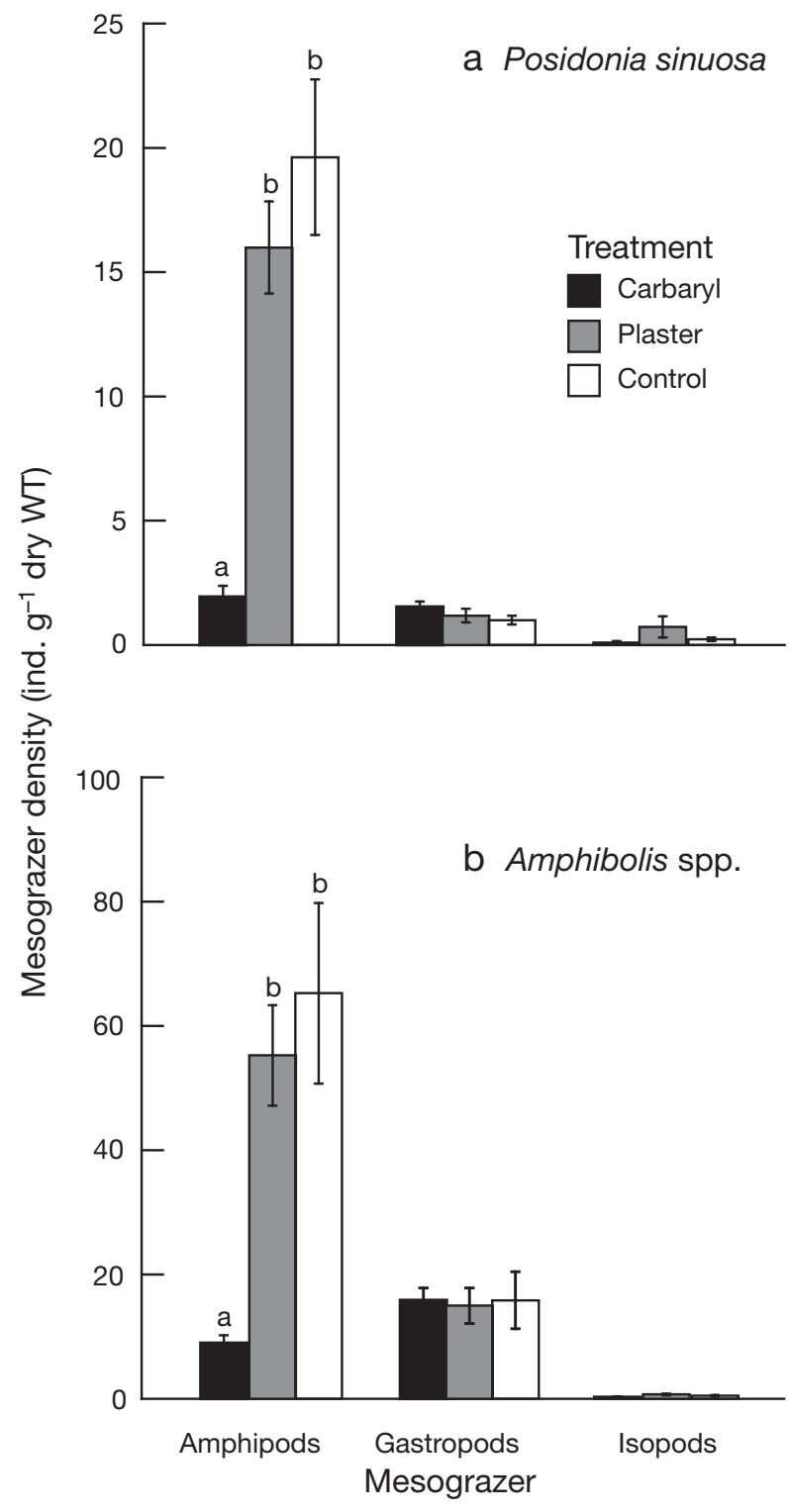

Fig. 1. Abundance of gammaridean amphipods, gastropods and isopods (mean $\pm \mathrm{SE}, \mathrm{n}=10$ ) in each treatment in (a) Posidonia and (b) Amphibolis meadows at the end of the 7 wk field experiment. Significant differences among treatments yielded by Tukey's tests are indicated by different letters above the bars 
Table 1. Analysis of covariance contrasting mesograzer abundance among experimental treatments (carbaryl, control and plaster plots) in Posidonia and Amphibolis meadows. Data were log transformed. Significant effects (p < 0.05) are shown in bold

\begin{tabular}{|c|c|c|c|c|c|c|c|c|c|c|}
\hline \multirow[t]{2}{*}{ Source } & \multirow[t]{2}{*}{ df } & \multicolumn{3}{|c|}{ Amphipods } & \multicolumn{3}{|c|}{ - Isopods- } & \multicolumn{3}{|c|}{ Gastropods- } \\
\hline & & MS & $F$ & $\mathrm{p}$ & MS & F & $\mathrm{p}$ & MS & $F$ & $\mathrm{p}$ \\
\hline \multicolumn{11}{|l|}{ Posidonia meadow } \\
\hline Treatment & 2 & 7.165 & 76.232 & $<0.001$ & 0.205 & 2.942 & 0.061 & 0.151 & 1.629 & 0.205 \\
\hline Seagrass (covariate) & 1 & 1.673 & 17.797 & $<0.001$ & 0.069 & 0.986 & 0.325 & 1.803 & 19.491 & $<0.001$ \\
\hline Error & 56 & 0.094 & & & 0.070 & & & 0.092 & & \\
\hline \multicolumn{11}{|l|}{ Amphibolis meadow } \\
\hline Treatment & 2 & 4.015 & 77.966 & $<0.001$ & 0.200 & 3.115 & 0.052 & 0.134 & 1.141 & 0.327 \\
\hline Seagrass (covariate) & 1 & 0.655 & 12.716 & 0.001 & 0.197 & 3.057 & 0.086 & 0.229 & 1.944 & 0.169 \\
\hline Error & 56 & 0.051 & & & 0.064 & & & 0.118 & & \\
\hline
\end{tabular}

tively; Fig. 1b). In both seagrass meadows, there was no significant difference in amphipod density between control and plaster plots (Fig. 1). Carbaryl did not strongly affect the abundance of other taxonomic groups of mesograzers (isopods and gastropods) in either seagrass meadow (Table 1); there was a trend for lower densities of isopods, but this trend was not statistically significant.

In the Posidonia meadow, the lower amphipod densities in carbaryl plots were associated with a $25 \%$ higher mean dry weight of epiphytes than in control or plaster plots $(0.40 \pm 0.04$ versus $0.30 \pm$ $0.02 \mathrm{~g}$ epiphyte $\mathrm{g}^{-1}$ seagrass, respectively; Fig. 2a, Table 2). There was no difference between the control and plaster plots. The lower amphipod densities and higher epiphyte biomass were not associated with any significant differences in seagrass biomass $\left(F_{2,57}=0.46, \mathrm{p}=0.64\right)$.

In the Amphibolis meadow, the lower amphipod densities did not result in large differences in the biomass of leaf epiphytes; there was a trend for higher epiphyte biomass in plots with carbaryl, but this trend was narrowly non-significant $\left(F_{2,57}=2.92, \mathrm{p}=0.06\right)$. There were no trends apparent in either calcareous or non-calcareous stem epiphytes (Table 2, Fig. 2b,c), or in seagrass biomass $\left(F_{2,57}=0.15, \mathrm{p}=0.86\right)$.

\section{DISCUSSION}

Reduction in amphipod densities was associated with increased biomass of epiphytic macroalgae on Posidonia sinuosa, providing clear evidence that natural densities of herbivorous amphipods can exert a strong influence on primary producers (Fig. 2). This provides supporting evidence to an increasing number of studies in mesocosms that indicate the potential of mesograzers to strongly alter benthic commu-

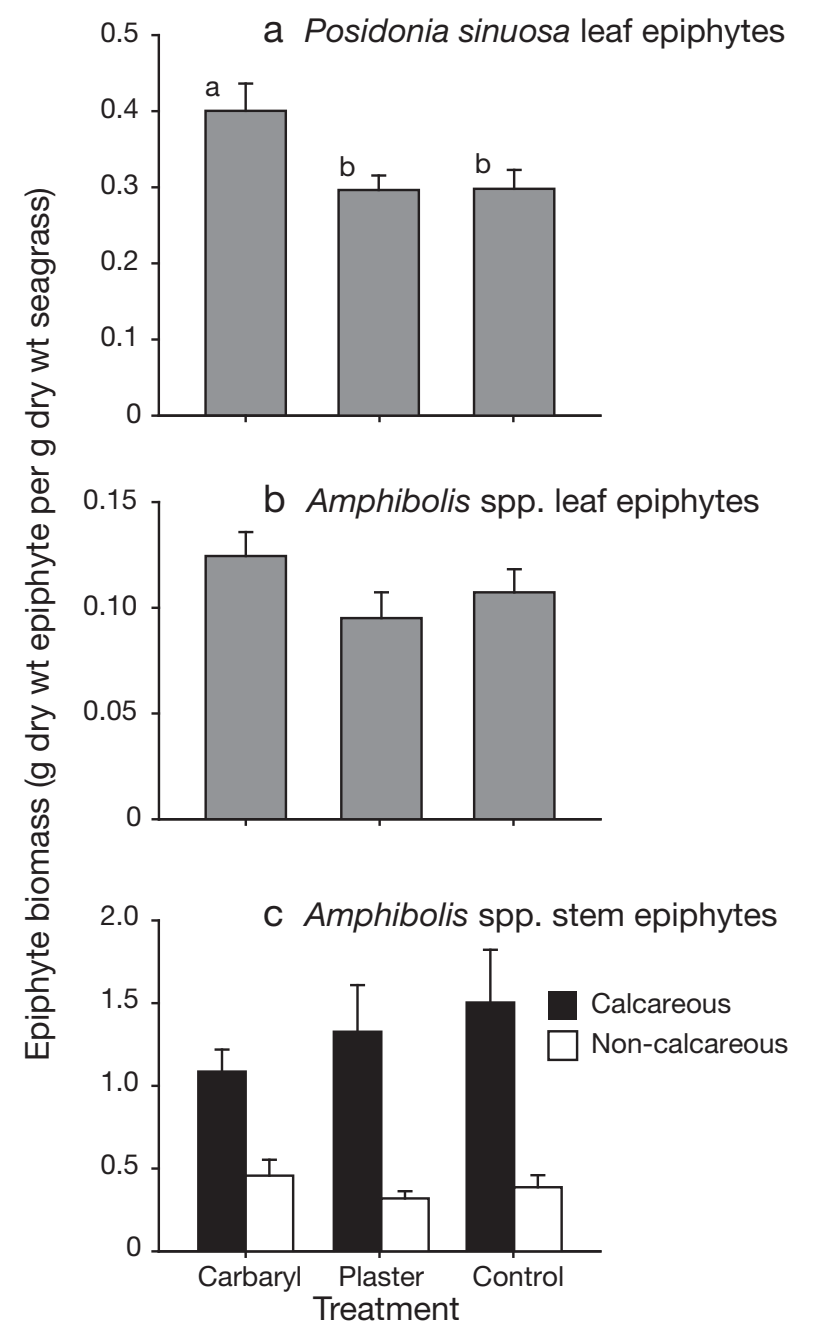

Fig. 2. Biomass (mean $\pm \mathrm{SE}, \mathrm{n}=10$ ) of (a) leaf epiphytes on Posidonia sinuosa, (b) leaf epiphytes on Amphibolis spp., and (c) calcareous and non-calcareous epiphytes on stems of Amphibolis spp. at the end of the $7 \mathrm{wk}$ field experiment. Significant differences (where present) among experimental treatments yielded by Tukey's tests are indicated by different letters above the bars 
Table 2. Analyses of covariance contrasting epiphyte biomass among experimental treatments (carbaryl, control and plaster) in Posidonia and Amphibolis meadows. Epiphytes were divided into leaf epiphytes (both seagrasses) and calcareous and noncalcareous stem epiphytes (Amphibolis only). Data were log transformed. Significant effects $(p<0.05)$ are shown in bold

\begin{tabular}{|c|c|c|c|c|c|c|c|c|c|c|}
\hline \multirow[t]{2}{*}{ Source } & \multirow[t]{2}{*}{ df } & \multicolumn{3}{|c|}{ Leaf epiphytes } & \multicolumn{3}{|c|}{ Calcareous stem epiphytes } & \multicolumn{3}{|c|}{ Non-calcareous stem epiphytes } \\
\hline & & MS & F & $\mathrm{p}$ & MS & $F$ & $\mathrm{p}$ & MS & F & $\mathrm{p}$ \\
\hline \multicolumn{11}{|l|}{ Posidonia sinuosa } \\
\hline Treatment & 2 & 0.034 & 6.781 & 0.002 & & & & & & \\
\hline Seagrass (covariate) & 1 & 1.472 & 289.831 & $<0.001$ & & & & & & \\
\hline Error & 56 & 0.005 & & & & & & & & \\
\hline \multicolumn{11}{|l|}{ Amphibolis spp. } \\
\hline Treatment & 2 & 0.013 & 2.917 & 0.062 & 0.002 & 0.028 & 0.973 & 0.023 & 0.728 & 0.487 \\
\hline Seagrass (covariate) & 1 & 0.138 & 30.927 & $<0.001$ & 0.153 & 1.737 & 0.193 & 1.282 & 40.788 & $<0.001$ \\
\hline Error & 56 & 0.004 & & & 0.088 & & & 0.031 & & \\
\hline
\end{tabular}

nities (e.g. Neckles et al. 1993, Duffy \& Hay 2000, Duffy et al. 2001, Jaschinski \& Sommer 2008).

The exclusion of grazers in situ is one of the most powerful techniques to identify the ecological role of herbivores, and decades of exclusion experiments with large marine herbivores have led to an excellent understanding of their impacts on benthic communities. Despite the expectations derived from mesocosm or laboratory studies that mesograzers can limit epiphytic growth (Valentine \& Duffy 2006), we are aware of relatively few previous studies that have experimentally excluded mesograzers in field conditions (all using cages or chambers) to establish their grazing impacts on epiphytes. Jernakoff \& Nielsen (1997) found that, despite some artefacts associated with their exclusion chambers, the presence of amphipods reduced the number of epiphyte species present on Posidonia sinuosa in Western Australia but had no effect on the biomass of epiphytes. Furthermore gastropods reduced biomass but did not alter species richness of epiphytes. Reduction of epiphyte biomass by small molluscs was also demonstrated by exclusion experiments in beds of Zostera marina in Canada (Robertson \& Mann 1982) and $Z$. japonica in Hong Kong (Fong et al. 2000). Other studies reduced mesograzer abundance within cages using predatory fish, but reported mixed effects due to omnivory by fish (Heck et al. 2000, 2006).

Our method differed from caging experiments in that it excluded a single group of grazers while others of similar sizes remained at natural densities. Carbaryl is known to affect the nervous system of terrestrial arthropods (Tomlin 2000), and may have a similar effect on amphipods in the marine environment. Similarly, the slight (but non-significant) reduction in isopod numbers may indicate some effects on isopods; however, we consider it unlikely that isopods strongly influence the biomass of epiphytes in our study area due to their very low numbers (see Fig. 1). Gastropods remained unaffected by treatment with carbaryl in our study, a similar result to previous studies (Duffy \& Hay 2000). Similarly, terrestrial gastropods are not known to be affected by carbaryl (Tomlin 2000). Previous studies have also demonstrated a lack of effect on fishes (pinfish; Duffy \& Hay 2000) so we consider it unlikely that our treatment had any effect on fishes that may be amphipod predators. Predators that are crustaceans may have been affected, but if this was the case, their decrease did not result in a compensatory increase in amphipod numbers.

The strong effects of amphipods observed in the Posidonia meadow were not observed in the Amphibolis meadow. Although there was a narrowly nonsignificant trend for higher biomasses of leaf epiphytes in the absence of amphipods, we cannot unambiguously extend the conclusions about the effects of amphipods to the Amphibolis meadow (see Fig. 2). It is unlikely that the impacts of amphipods will be uniform across habitats. For example, in the only other published experiment to exclude grazing amphipods using this cageless technique, Poore et al. (2009) found no effect of reduced amphipod densities on the cover of epiphytes on the brown alga Sargassum linearifolium in a temperate algal bed in eastern Australia. It is therefore likely that the influence of amphipods will vary among meadows of different seagrasses, depending on the density of amphipods and other mesograzers (Tuya et al. 2010, present study), the biomass and species composition of epiphytic macroalgae (Lavery \& Vanderklift 2002), as well as the morphology of the seagrass host. Other factors, such as wave energy or currents, may also contribute to differences among seagrass meadows. Resolving whether these differences do indeed exist, and the circumstances in 
which they occur, remains a challenge for ecologists.

We found no effects of amphipods on the biomass of seagrass itself, in either Posidonia or Amphibolis meadows. It has been suggested that direct grazing on seagrass by mesograzers is minimal, and that the primary impact of mesograzers in seagrass meadows is expected to be mediated by their control of epiphytes (e.g. Duffy \& Harvilicz 2001). If epiphytes attain abundances that negatively affect the seagrass host, a decrease in seagrass biomass often follows. In our study, the decrease in the biomass of epiphytes was not sufficient in the duration of the experiment to influence the seagrass host. We are unable to infer from this whether the epiphytes do not affect the seagrass (although the results of Cambridge et al. 2007 suggest that they do), or whether epiphyte biomass may not have been sufficient or the duration of the experiment too short to cause a decline in the seagrass host. In mesocosm studies elsewhere in the world, negative effects of increasing epiphyte biomass on seagrasses after mesograzer exclusion are common, but not universal. Several studies have demonstrated that grazer exclusion results in large increases in epiphyte biomass that are not associated with declines in seagrass biomass (reviewed in Valentine \& Duffy 2006). The variation in the results reported demonstrates that much remains to be done before indirect effects of mesograzers on seagrasses are fully understood.

We provide evidence of a strong influence on epiphytic macroalgae by natural densities of amphipods yielded by a cageless field experiment. Reduced densities of amphipods resulted in higher epiphyte biomass, but the effect varied between seagrass meadows. The ubiquity of mesograzers and epiphytic algae as components of nearshore habitats suggests that similar patterns are likely to occur elsewhere.

Acknowledgements. This study arose from discussion at a workshop funded by the ARC-NZ Research Network for Vegetation Function. We thank M. Westoby, A. Nicotra and S. Newton for funding and support of the workshop. The research was supported by the CSIRO Marine \& Atmospheric Research Capability Development Fund and the Western Australian Marine Science Institution. P. Vouriot, B. Munkes, F. Graham and D. Thomson provided assistance in the field. Thanks to A. Campbell, B. Munkes and 3 anonymous reviewers for comments that improved the manuscript.

\section{LITERATURE CITED}

Aikins S, Kikuchi E (2002) Grazing pressure by amphipods on microalgae in Gamo Lagoon, Japan. Mar Ecol Prog Ser 245:171-179
Armhurst KL, Grosby DG (1991) Fate of carbaryl, 1-naphthol and atrazine in seawater. Pac Sci 45:314-320

Brawley SH, Fei XG (1987) Studies of mesoherbivory in aquaria and in an unbarricaded mariculture farm on the Chinese coast. J Phycol 23:613-623

Bruno JF, Boyer KE, Duffy JE, Lee SC, Kertesz JS (2005) Effects of macroalgal species identity and richness on primary production in benthic marine communities. Ecol Lett 8:1165-1174

> Cambridge ML, How JR, Lavery PS, Vanderklift MA (2007) Retrospective analysis of epiphyte assemblages in relation to seagrass loss in a eutrophic coastal embayment. Mar Ecol Prog Ser 346:97-107

- Carpenter RC (1986) Partitioning herbivory and its effects on coral reef algal communities. Ecol Monogr 56: 345-363

Davenport AC, Anderson TW (2007) Positive indirect effects of reef fishes on kelp performance: the importance of mesograzers. Ecology 88:1548-1561

$>$ Douglass JG, Duffy JE, Spivak AC, Richardson JP (2007) Nutrient versus consumer control of community structure in a Chesapeake Bay eelgrass habitat. Mar Ecol Prog Ser 348:71-83

Douglass JG, Duffy JE, Bruno JF (2008) Herbivore and predator diversity interactively affect ecosystem properties in an experimental marine community. Ecol Lett 11: $598-608$

$>$ Duffy JE, Harvilicz AM (2001) Species-specific impacts of grazing amphipods in an eelgrass-bed community. Mar Ecol Prog Ser 223:201-211

Duffy JE, Hay ME (2000) Strong impacts of grazing amphipods on the organization of a benthic community. Ecol Monogr 70:237-263

Duffy JE, Macdonald KS, Rhode JM, Parker JD (2001) Grazer diversity, functional redundancy, and productivity in seagrass beds: an experimental test. Ecology 82: $2417-2434$

> Edgar GJ (1990) Population regulation, population dynamics and competition amongst mobile epifauna associated with seagrass. J Exp Mar Biol Ecol 144:205-234

Edgar GJ (1992) Patterns of colonization of mobile epifauna in a Western Australian seagrass bed. J Exp Mar Biol Ecol 157:225-246

Fong CW, Lee SP, Wu RSS (2000) The effects of epiphytic algae and their grazers on the intertidal seagrass Zostera japonica. Aquat Bot 67:251-261

> Graham MH (2002) Prolonged reproductive consequences of short-term biomass loss in seaweeds. Mar Biol 140: 901-911

> Haggitt TR, Babcock RC (2003) The role of grazing by the lysianassid amphipod Orchomenella aahu in dieback of the kelp Ecklonia radiata in north-eastern New Zealand. Mar Biol 143:1201-1211

Heck KL, Valentine JF (2006) Plant-herbivore interactions in seagrass meadows. J Exp Mar Biol Ecol 330:420-436

$>$ Heck KL, Pennock JR, Valentine JF, Coen LD, Sklenar SK (2000) Effects of nutrient assessment and small predator density on seagrass ecosystems: an experimental assessment. Limnol Oceanogr 45:1041-1057

> Heck KL Jr, Valentine JF, Chaplin G, Spitzer PM (2006) Effects of nutrient enrichment and grazing on shoalgrass Halodule wrightii and its epiphytes: results of a field experiment. Mar Ecol Prog Ser 326:145-156

Hughes AR, Bando KJ, Rodriguez LF, Williams SL (2004) Relative effects of grazers and nutrients on seagrasses: a 
meta-analysis approach. Mar Ecol Prog Ser 282:87-99

Jaschinski S, Sommer U (2008) Functional diversity of mesograzers in an eelgrass-epiphyte system. Mar Biol 154: 475-482

> Jernakoff P, Nielsen J (1997) The relative importance of amphipod and gastropod grazers in Posidonia sinuosa meadows. Aquat Bot 56:183-202

Jernakoff P, Brearley A, Nielsen J (1996) Factors affecting grazer-epiphyte interactions in temperate seagrass meadows. Oceanogr Mar Biol Annu Rev 34:109-162

Korpinen S, Jormalainen V, Honkanen T (2007) Effects of nutrients, herbivory, and depth on the macroalgal community in the rocky sublittoral. Ecology 88:839-852

Lavery PS, Vanderklift MA (2002) A comparison of spatial and temporal patterns in epiphytic macroalgal assemblages of the seagrasses Amphibolis griffithii and Posidonia coriacea. Mar Ecol Prog Ser 236:99-112

Lubchenco J, Gaines SD (1981) A unified approach to marine plant-herbivore interactions. Annu Rev Ecol Syst 12:405-437

Neckles HA, Wetzel RL, Orth RJ (1993) Relative effects of nutrient enrichment and grazing on epiphyte-macrophyte (Zostera marina L.) dynamics. Oecologia 93:285-295

Poore AGB (2005) Scales of dispersal among hosts in a herbivorous marine amphipod. Austral Ecol 30:219-228

Poore AGB, Campbell AH, Steinberg PD (2009) Natural densities of mesograzers fail to limit growth of macroalgae or their epiphytes in a temperate algal bed. J Ecol 97:

Editorial responsibility: Kenneth Heck,

Dauphin Island, Alabama, USA
$164-175$

> Robertson AI, Mann KH (1982) Population dynamics and life history adaptations of Littorina neglecta Bean in an eelgrass meadow (Zostera marina L.). J Exp Mar Biol Ecol 63:151-171

Shacklock PF, Croft GB (1981) Effect of grazers on Chondrus crispus in culture. Aquaculture 22:331-342

Shurin JB, Gruner DS, Hillebrand H (2006) All wet or dried up? Real differences between aquatic and terrestrial food webs. Proc R Soc Lond B Biol Sci 273:1-9

Silberstein K, Chiffings AW, McComb AJ (1986) The loss of seagrass in Cockburn Sound, Western Australia. III. The effect of epiphytes on productivity of Posidonia australis Hook. F. Aquat Bot 24:355-371

- Taylor RB (1998) Seasonal variation in assemblages of mobile epifauna inhabiting three subtidal brown seaweeds in northeastern New Zealand. Hydrobiologia 361: 25-35

Tomlin CDS (ed) (2000) The pesticide manual: a world compendium. British Crop Protection Council, Plymouth

Tuya F, Vanderklift MA, Hyndes GA, Wernberg T, Thomsen MS, Hanson C (2010) Proximity to rocky reefs alters the balance between positive and negative effects on seagrass fauna. Mar Ecol Prog Ser 405:175-186

> Valentine JF, Duffy JE (2006) The central role of grazing in seagrass ecology. In: Larkum AWD, Orth RJ, Duarte CM (eds) Seagrasses: biology, ecology and conservation. Springer, Dordrecht, p 463-501

Submitted: June 21, 2011; Accepted: October 10, 2011

Proofs received from author(s): November 22, 2011 